\title{
Strategi Linguistik Forensik
}

$\mathbf{P}$

UBLIK pernah dikejutkan dengan kabar penolakan tersangka untuk memberikan sampel suaranya di KPK. Adalah tersangka LCS, seorang advokat, dijerat dengan delik menghalang-halangi penyidikan oleh KPK. Dalam kasusnya, LCS diduga telah membantu ESI, kliennya untuk melarikan diri. ESI sendiri sejak 2016 oleh KPK sudah ditetapkan menjadi tersangka dalam sebuah kasus suap di pengadilan. Dan LCS berupaya mengajukan praperadilan terhadap kasusnya di PN Jakarta Selatan. Bagi KPK, sampel suara tersangka akan dibandingkan dengan suara hasil penyadapan.

\section{Kewenangan}

Kewenangan KPK untuk melakukan penyadapan dan merekam pembicaraan dalam melaksanakan tugas penyelidikan, penyidikan, dan penuntutan, disebutkan dengan jelas dalam Undang-Undang (UU) Nomor 32 Tahun 2002. Oleh karena itu, dengan kewenangan tersebut, KPK dapat melakukan penyadapan dan memiliki alat bukti rekaman sadapan suara tersangka. Kemudian, KPK memerlukan sampel suara tersangka untuk dicocokkan dengan bukti sadapan tersebut. Namun, dalam kasus LCS, sampel suara belum didapatkan karena tersangka menolak memberikannya.

\section{Dua potensi}

da dua masalah yang bisa ditimbulkan dari penolakan

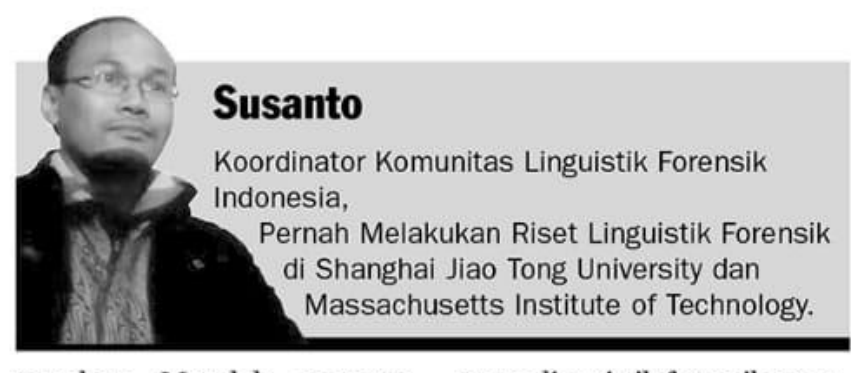

tersebut. Masalah pertama adalah tidak tersedianya data pembanding berupa sampel suara tersangka untuk analisis forensik suara. Seperti yang diuraikan oleh Dr Philip Rose (2002) dalam bukunya Forensic Speaker Identification, analisis forensik suara memerlukan sampel suara sebagai data pembanding. Dalam hal ini, analisis sampel suara sangat diperlukan untuk dibandingkan dengan suara yang terdapat dalam alat bukti rekaman sadapan.

Masalah kedua adalah jika tersangka-tersangka lainnya mengikuti apa yang telah dilakukan oleh LCS. Dengan demikian, jika KPK tidak memiliki strategi lain untuk mendapatkan sampel suara tersangka, ini bisa menimbulkan masalah baru yang rumit di masa yang akan datang. Lalu bagaimana caranya untuk melakukan analisis forensik suara jika tersangka masih tetap menolak memberikan sampel suara? Untuk mengatasinya, linguistik forensik menawarkan sebuah strategi yang dapat dilakukan terkait dengan masalah ini.

Strategi

Mungkin bagi sebagian orang, linguistik forensik merupakan istilah yang baru didengar. Namun, tidak bagi para ahli bahasa yang pernah memberikan kesaksian ahli untuk perkara kasus-kasus hukum di Indonesia. Bahkan di tanah air sudah ada Komunitas Linguistik Forensik Indonesia (KLFI) Dalam komunitas itu, para anggotanya berbagi literatu dan membahas kajian-kajian ilmu bahasa dan peranannya dalam beragam kasus hukum di Indonesia.

Awalnya, istilah linguistik forensik ini muncul di Inggris pada tahun 1968. Saat itu, seorang ahli bahasa yang bernama Jan Startvik menggunakan istilah linguistik forensik dalam laporan hasil kerjanya. Laporannya terkait dengan kasus pembunuhan terhadap seorang ibu muda bernama Beryl Susan Evans dan Geraldine, bayi perempuannya yang masih berumur 14 bulan. Sejak itu, peran inguistik forensik semakin dirasa sangat diperlukan dan mulailah dilakukan kajian demi kajian.

Sebagai ilmu "terapan" bahasa dalam bidang hukum, inguistik forensik memiliki tig wilayah eksplorasi yaitu anali- sis bahasa dalam proses hukum, analisis bahasa dalam produk hukum dan analisis bahasa dalam alat bukti hukum. Ketiga wilayah ini sangatlah kompleks dan penuh tantangan ketika dihadapkan dengan realitas hukum di lapangan. Misalnya saja untuk analisis bahasa dalam alat bukti hukum berupa rekaman suara tersangka. Salah satu tantangan terbesarnya adalah ketika tersangka menolak memberikan sampel suaranya seperti yang terjadi pada kasus LCS. Dalam linguistik forensik, hal ini dapat diatasi dengan sebuah strategi. Yaitu, pengambilan data suara tersangka dengan wacana autentik.

\section{Data suara}

Dalam proses penyidikan, penolakan tersangka untuk memberikan sampel suara bisa menjadi masalah karena analisis forensik suara bisa terhambat. Tetapi dalam linguistik forensik ada sebuah strategi untuk tetap dapat melakukan analisis forensik suara yaitu dengan mengambil data dari wacana autentik. Wacana autentik adalah wacana asli (apa adanya) ketika seseorang menggunakan bahasa lisan dan tulis. Untuk analisis forensik suara, sampel dapat diambil dengan merekam wacana autentik ketika tersangka berbicara selama di dalam proses penyidikan atau di luar proses penyidikan. Kemudian, dalam uji forensik suara dilakukan analisis perbandingan suara dari rekaman wacana autentik dan sadapan dengan membangun pencirian 3 unsur linguistik yaitu leksikogramatika, fonologi, dan fonetik.

Apakah KPK memiliki kewenangan untuk itu? Pasal $12 \mathrm{UU}$ Nomor 32 Tahun 2002 memberikan kewenangan secara hukum kepada KPK bukan hanya untuk menyadap tapi juga untuk merekam pembicaraan demi melaksanakan tugas penyelidikan, penyidikan, dan penuntutan. Kewenangan untuk "merekam pembicaraan" inilah yang dapat menjadi landasan hukum KPK untuk melakukan strategi linguistik forensik dalam merekam wacana autentik tersangka ketika berbicara.

Dengan strategi ini, walaupun tersangka menolak untuk memberikan sampel suaranya, penyidik masih dapat memiliki sampel dari data suara tersangka dengan wacana autentik. Dengan demikian, proses uji forensik terhadap suara rekaman sadapan yang dijadikan sebagai alat bukti bisa tetap dilakukan dengan 2 hipotesis.

Penutur suara dalam rekaman sadapan yang diinvestigasi sama dengan penutur suara dalam rekaman wacana autentik pembanding; penutur suara dalam rekaman sadapan yang diinvestigasi tidak sama dengan penutur suara dalam rekaman wacana autentik pembanding.

Diharapkan, dengan strategi linguistik forensik ini, KPK akan tetap bisa bekerja secara maksimal demi menjalankan tugas, wewenang dan kewajibannya. ${ }^{* * *}$ 